\title{
ANALYSIS OF MITOCHONDRIAL DNA IN HONEY BEES (APIS MELLIFERA) FROM SERBIA
}

\author{
KOZMUS P*, STEVANOVIĆ JEVROSIMA**, STANIMIROVIĆ Z**, STOJIĆ V**, KULIŠIĆ Z** \\ and MEGLIC V* \\ ${ }^{\star}$ Agricultural Institute of Slovenia, Ljubljana, Slovenia \\ **Faculty of Veterinary Medicine, University of Belgrade
}

(Received 1. May 2007)

In this study mitochondrial DNA of the indigenous honey bee populations from Serbia was analysed. Three ecotypes were comprised in the investigation: Banat (B), Syenichko-Peshterski (S) and Timok $(T)$. The results show that all investigated samples of honey bees from Serbia belong to one mtDNA haplotype of the $C$ phylogenetic lineage, previously designated as C2D haplotype, though with three additional polymorphic sites. For the novel mtDNA haplotype, the designation $C 2 E$ is proposed. The novel C2E haplotype differs from C2D in two A-T transversions and in one insertion. Moreover, within the $T$ honey bee ecotype, two additional polymorphic sites were observed; a deletion of a T nucleotide and a T-C transition. Our results suggest that the Carniolan honey bee populations from Serbia may represent an indigenous gene pool within A. m. carnica. The mtDNA haplotype (C2D), previously found in A. m. macedonica, was found in all samples of Serbian A. m. carnica. This suggests that the C2D haplotype may be found within both subspecies. This study represents the first effort to characterize the indigenous honey bee populations in Serbia using molecular techniques with the objective of improving our understanding of the phylogeography of Apis mellifera.

Key words: A. m. carnica, molecular characterization, mtDNA, novel C2E haplotype, phylogeography, Serbia

\section{INTRODUCTION}

The Carniolan honey bee, Apis mellifera carnica Pollmann, is native to regions of the former Yugoslavia (Serbia, Montenegro, Macedonia, Bosnia and Hercegovina, Croatia, Slovenia), southern Austria, and parts of Hungary, Romania, and Bulgaria (Ruttner, 1988). A. m. carnica expanded from its native range to the central and northern European countries, the United States, Canada and to other parts of the world through the practice of exportating live honey bees. In contrast to the spread of $A$. $m$. mellifera, this happened in the second wave of artificial honey bee colonisation, in the second half of the 19th century. The main 
reasons for the widespread popularity of $A$. m. carnica included gentle behaviour, quick spring buildup of colonies and good summer honey production (Ruttner, 1992).

A. $m$. carnica belongs to the north Mediterranean lineage $C$ according to morphometric analyses (Ruttner, 1988). However, morphological characters are not well suited for phylogeographic studies because they can be sensitive to environmental selection and, in that respect, mitochondrial DNA (mtDNA) is a much better genetic marker (Avise et al., 1987; Franck et al., 2000a). An advantage of mitochondrial data over morphometric data is that DNA sequence data can be analysed easily in a phylogenetic context. This is desirable for inferring the relationships among populations and for inferring the history of population movements (Palmer et al., 2000). Variation in mtDNA is useful both for identification and for phylogenetic analysis of honey bee subspecies (Smith and Brown, 1988). Consequently, the honey bee mitochondrial genome has provided a lot of data for studies of $A$. mellifera phylogeny and biogeography (Smith et al, 1991; Garnery et al., 1992; Meixner et al., 1993, 2000; Moritz et al., 1994; Sheppard et al., 1996; Arias and Sheppard, 1996; Franck et al. 1998, 2000a,b; Palmer et al., 2000; De la Rúa et al., 2001a,b, 2006; Bouga et al., 2005; Kandemir et al., 2006a,b). Five evolutionary lineages of honey bees have been delineated using mtDNA analysis, studying the highly variable COI-COII region (Smith and Brown, 1988; Cornuet et al., 1991; Garnery et al., 1992; Arias and Sheppard, 1996; Franck et al., 2000a, 2001; Palmer et al., 2000) and it was revealed that $A$. $m$. carnica belongs to the eastern Mediterranean mitochondrial lineage ( $C$ mtDNA lineage). However, it should be noted that the importation of foreign queens presents a situation where hybridization can change the distribution of mtDNA variants found in the genetic pool of local bees (Bouga et al., 2005).

The variability in the COI-COII region results from the superimposition of length variation (presence/absence of the $P$ sequence, number of reiterated $Q$ sequences, possible small deletions) and nucleotide substitutions. The shortest haplotypes that lack the $P$ sequence and possess a single $Q$ sequence are characteristic of the $C$ lineage (Cornuet et al., 1991). Short size and absence of length variability in the COI-COIl region results in a reduced potential for pattern variability in this lineage (Garnery et al., 1993). So far, five haplotypes have been described within the $C$ lineage, foremost $C 1$ in A. m. ligustica, C2A in A. m. carnica and $\mathrm{C} 2 \mathrm{~B}$ in $A$. m. caucasica (Franck et al., 2000b), and later, C2D in A. m. macedonica and $\mathrm{C} 2 \mathrm{C}$ in A. m. carnica in Slovenia and Croatia (Sušnik et al., 2004). These haplotypes differ in only five polymorphic sites (one insertion/deletion and four transitions) (Franck et al., 2000b; Sušnik et al., 2004).

Because the territory of Serbia is located in the center of the distribution area of the Mediterranean evolutionary branch $\mathrm{C}$, and no investigations of honey bees from Serbia have been conducted using molecular techniques, we investigated honey bees from three Serbian regions, using mitochondrial DNA analyses. Previous investigations of honey bees from Serbia revealed cytogenetic and morphometric differences among three ecotypes (Banat (B), SyenichkoPeshterski (S) and Timok (T)) (Stanimirovic et al., 1999a,b; Stevanovic, 2002; Stanimirovic et al., 2005a), as well as the differences in hygienic and grooming 
behaviours within and among the same ecotypes (Stanimirovic et al., 2002, 2003, 2005b). The first genetic investigations of honey bees from Serbia revealed differences in the biometric and ultrastructural organizations of chromosomes between the B and S honey bee ecotypes (Stanimirovic et al., 1999a,b). Later, chromosomal investigations comprising the three honey bee ecotypes from Serbia (B, S and T) demonstrated the existence of a G-band polymorphism. The greatest cytogenetic differences exist between the $S$ and $B$ honey bee ecotypes, fewer between the $T$ and $B$ ecotypes and least between the $S$ and $T$ ecotypes (Stanimirovic et al., 2005a). These results were in concordance with results obtained by morphometric analysis of the same ecotypes using 30 morphometric characters (Stevanovic, 2002). However, additional studies of the same ecotypes at the molecular level are necessary to provide higher resolution of ecotype relationships.

In this study we analyzed the mtDNA of B, S and T honey bee ecotypes as the initial step of molecular characterization of the indigenous honey bee populations from Serbia. This is the first time that the honey bees from Serbia have been analyzed using a molecular approach, and the results may improve our understanding of the phylogeography of $A$. mellifera.

\section{MATERIAL AND METHODS}

\section{Sampling}

A total of 30 honey bee colonies, one colony per locality, were sampled from three Serbian regions: Banat (B), Timok (T) and Syenica-Peshter (S). These regions, which are some $200 \mathrm{~km}$ apart, have different climatic, geographic and floristic features and were described in detail by Stanimirovic et al. (2005a). The sampling was done at 10 localities in each specified region. The names and geographic distribution of the sampled sites are presented in Figure 1. Sampling was carried out from small apiaries that had existed on the same sites for at least 50 years, separated from other apiaries by at least $8 \mathrm{~km}$. In these apiaries, honey bee colonies were kept in traditional hives (woven skeps) which had never been moved. Requeening of colonies was strictly natural. As those apiaries were rather isolated and foreign queens had never been introduced into them, the genetic influence from other apiaries was presumed to be minimal. The skeps were lifted and the bees were trapped from the combs to prevent the collection of drifting bees. The bees were immobilised by immersion in absolute ethanol and kept at $20^{\circ} \mathrm{C}$ until laboratory processing. All sampled colonies were previously characterised by morphometric and chromosomal analyses (Stevanovic, 2002; Stanimirovic et al., 2005).

\section{DNA extraction}

Total DNA was extracted from worker's legs. Each sample was ground in to a fine powder using liquid nitrogen. DNA was extracted using JETQUICH Tissue DNK Spin kit (Genomed) according to a slight modification of the protocol 
described by Bowtell (1987). DNA concentration was measured by fluorometer and, for further DNA analysis, the concentration of $100 \mathrm{ng} / \mu \mathrm{L}$ was used.

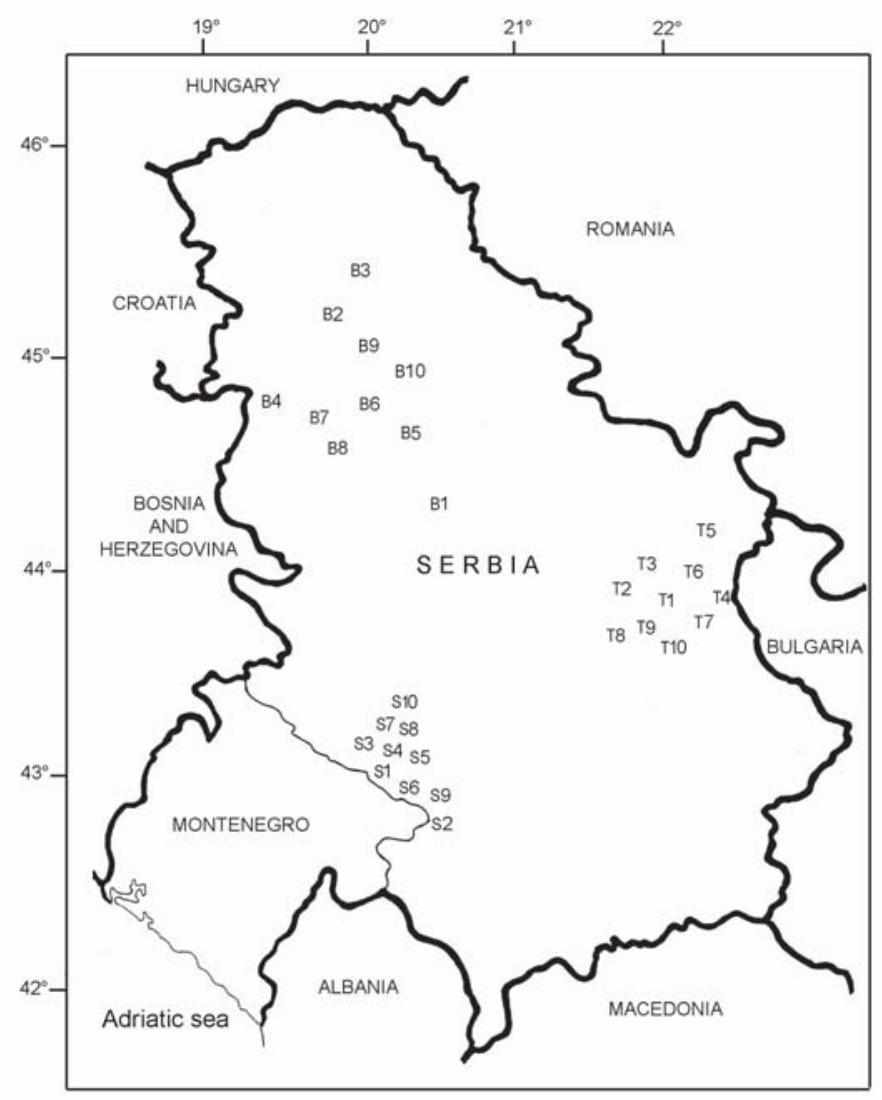

Figure 1. Geographical distribution of the sampled localities: Banat region (localities: B1. Belosavci; B2. Dumbovo; B3. Curug; B4. Dublje; B5. Ripanj; B6. Cerak; B7. Drenovac; B8. Sevarice; B9. Tabanovic; B10. Crna Bara); Timok region (localities: T1. Ilino; T2. Krivi Vir; T3. Lukovo; T4. Stupanj; T5. Metris; T6. Lubnica; T7. Vrazogrnac; T8. Sesalac; T9. Milusinac; T10. Levovik); Syenichko-Peshterski region (localities: S1. Vranovina; S2. Kocarnik; S3. Borostica; S4. Dubovo; S5. Cvijetlje; S6. Livadak; S7. Grabovica; S8. Sare; S9. Pavlje; S10. Gonje

\section{DNA amplification and sequencing}

The mtDNA region including the tRNA ${ }^{\text {Leu }}$ gene, the COI-COII intergenic region and the $5^{\prime}$ end of the COIl gene was amplified using primers E2 (5'- 
GGCAGAATAAGTGCATTG-3') and H2 (5'-CAATATCATTGATGACC-3') (Garnery et al., 1992). The PCR reaction mixture contained $1 \times$ Taq buffer (Roshe), $1.5 \mathrm{mM}$ $\mathrm{MgCl}_{2}, 1 \mu \mathrm{M}$ of each primer, $1 \mathrm{mM}$ of each dNTP, $0.6 \mathrm{U}$ of Taq polymerase (PE Applied Biosystems) and $1 \mu \mathrm{L}$ of DNA extract. The conditions for PCR were the following: initial denaturation $\left(94^{\circ} \mathrm{C}, 3 \mathrm{~min}\right)$ followed by 30 cycles of denaturation $\left(94^{\circ} \mathrm{C}, 45 \mathrm{~s}\right)$, primer annealing $\left(57^{\circ} \mathrm{C}, 45 \mathrm{~s}\right)$, and DNA extension $\left(72^{\circ} \mathrm{C}, 1 \mathrm{~min}\right)$. All PCR amplifications were performed in a programmable thermocycler GeneAmp ${ }^{\circledR}$ PCR System 9700 (AB Applied Biosystems). The size of the amplified COI-COII region was determined using a $7 \mu \mathrm{L}$ aliquot of the PCR product electrophoresed on a $1.5 \%$ agarose gel.

All sequencing reactions were prepared using a BigDye Terminator Ready Reaction Mic (PE Applied Biosystems) according to the manufacturer's recommendations. Region was sequenced using primers E2 and H2 (Garnery et al., 1993). Termination PCR reactions were performed in a programmable thermocycler under the following conditions: $10 \mathrm{~s}$ denaturation at $96^{\circ} \mathrm{C}, 5 \mathrm{~s}$ annealing at $50^{\circ} \mathrm{C}$ and 4 min extension at $60^{\circ} \mathrm{C}$, repeated for 30 cycles. The amplified, fluorescently labelled and terminated DNA was salt-precipitated and analysed on the automated sequencer ABI PRISM 310 (Perkin Elmer).

\section{Data analysis}

Sequences of the $5^{\prime}$-end of the mtDNA (490 bp) were aligned with published sequences of 44 different haplotypes of honey bees. Sequence alignments were done using the ClustalX software (Thompson et al., 1997). Maximum parsimony (MP) and Neighbour-Joining (NJ) analyses were performed using the BioEdit 7.0.5 software (Hall, 1999). Using the same program, pairwise sequence divergences between the investigated region were calculated and a basic phylogenetic tree was constructed.

\section{RESULTS}

The PCR-amplified COI-COII mtDNA region was found to exibit a length of $490 \mathrm{bp}$ for all samples examined. To define exact haplotypes, the PCR products of all samples were sequenced and the obtained sequences were aligned with published sequences of 44 different haplotypes of honey bees. All investigated samples of honey bees from Serbia belonged to the C2D mtDNA haplotype of the $\mathrm{C}$ phylogenetic lineage. This $\mathrm{C} 2 \mathrm{D}$ haplotype differs from the $A$. $m$. carnica-specific haplotype in two C-T transitions (Sušnik et al., 2004) and was previously found only in samples of $A$. m. macedonica and "Buckfast $\mathrm{J}$ " selected line of bees from Germany (Sušnik et al., 2004). Also, three novel polymorphic sites were found in all analysed samples (Figure 2). For this novel mtDNA haplotype, specific so far for the honey bees from Serbia, the designation C2E is proposed. The novel C2E haplotype differs from C2D in two A-T transversions and in one insertion. The comparison of the C2E haplotype to already published haplotypes is shown in Table 1. Moreover, in four samples $(40 \%)$ of the T honey bee ecotype (from localities T1-llino, T3-Lukovo, T5-Metris, T7-Vrazogrnac), one novel deletion of a T 
nucleotide was observed. This deletion is located six nucleotides from nucleotide $\mathrm{C}$, which is already designated as polymorphic site 2 . Within the same T ecotype, novel T-C transition was observed in one sample (10\%) originated from locality T1llino. Pair-wise genetic distance estimates for all honey bee haplotypes of the C mtDNA lineage and the number of nucleotide differences between them are shown in Table 2 . The reconstruction of phylogeny by both parsimony and neighbour-joining methods revealed similar tree-topology of haplotypes (Figure 3).

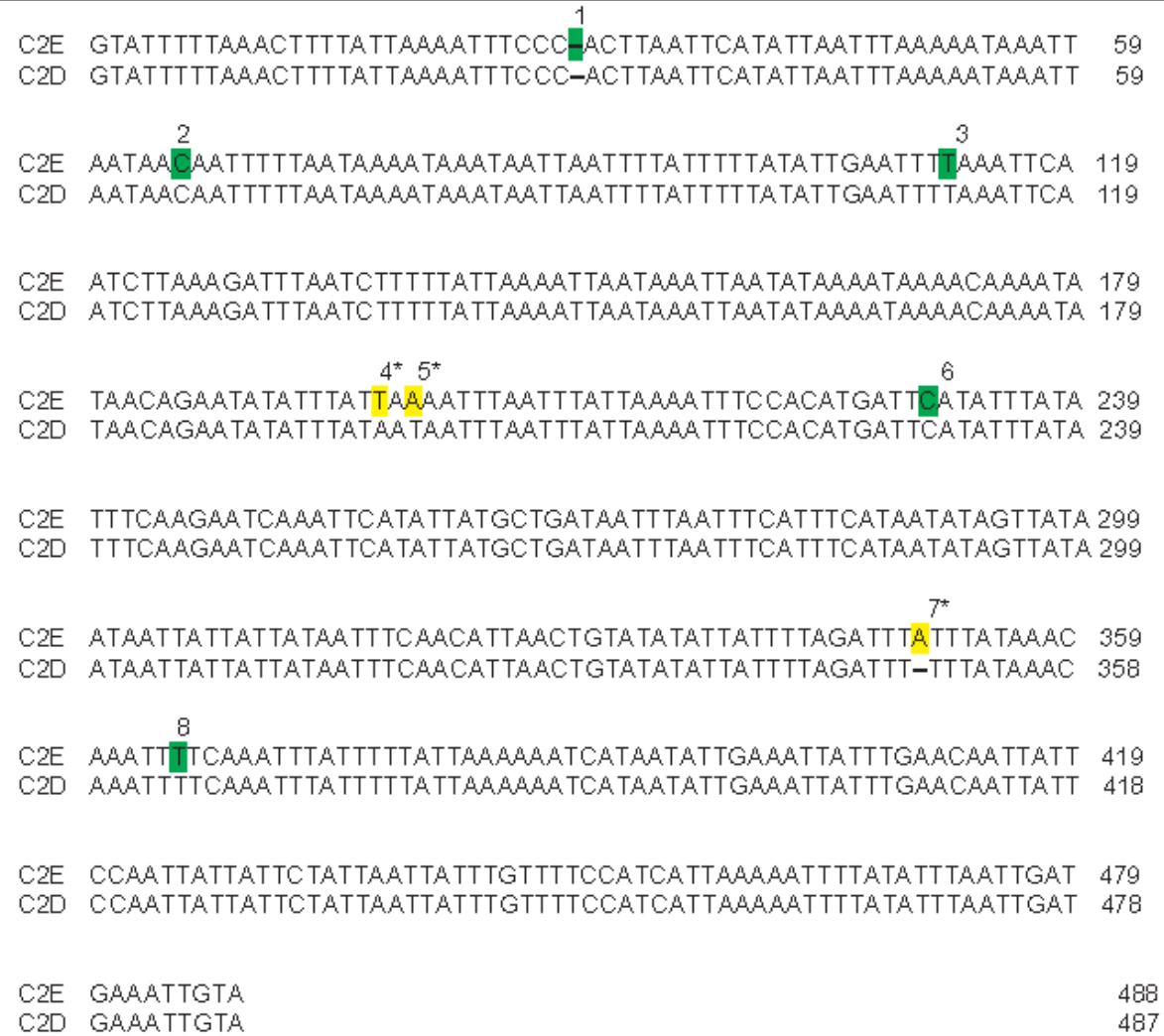

Figure 2. Two aligned sequences and variable nucleotide positions in mtDNA COI-COII region (*indicates novel variable nucleotide position) 
Acta Veterinaria (Beograd), Vol. 57. No. 5-6, 465-476, 2007.

Kozmus $\mathrm{P}$ et al.: Analysis of mitochondrial DNA

in honey bees (Apis mellifera) from Serbia

Table 1. Nucleotides at five already described and three novel variable positions of COI-COII mtDNA region, differentiating haplotypes of $A$. mellifera $\mathrm{C}$ phylogenetic lineage

\begin{tabular}{|l|c|c|c|c|c|c|c|c|c|}
\hline \multirow{2}{*}{$\begin{array}{c}\text { Previously described } \\
\text { mtDNA haplotypes of the }\end{array}$} & \multicolumn{7}{|c|}{ Polymorphic site } \\
\cline { 2 - 11 } \begin{tabular}{l} 
C phylogenetic lineage \\
\cline { 2 - 11 }
\end{tabular} & 5 PS & 1 & 2 & 3 & & & 4 & & 5 \\
\hline \hline C1 (Franck et al., 2001) & & $\mathrm{C}$ & $\mathrm{C}$ & $\mathrm{T}$ & $\mathrm{A}$ & $\mathrm{T}$ & $\mathrm{T}$ & & $\mathrm{C}$ \\
\hline C2A (Franck et al., 2001) & & $\mathrm{d}$ & $\mathrm{A}$ & $\mathrm{T}$ & $\mathrm{A}$ & $\mathrm{T}$ & $\mathrm{C}$ & & $\mathrm{T}$ \\
\hline C2B (Franck et al., 2001) & & $\mathrm{d}$ & $\mathrm{C}$ & $\mathrm{A}$ & $\mathrm{A}$ & $\mathrm{T}$ & $\mathrm{C}$ & & $\mathrm{T}$ \\
\hline C2C (Sušnik et al. 2004) & & $\mathrm{d}$ & $\mathrm{C}$ & $\mathrm{T}$ & $\mathrm{A}$ & $\mathrm{T}$ & $\mathrm{T}$ & & $\mathrm{C}$ \\
\hline C2D (Sušnik et al. 2004) & & $\mathrm{d}$ & $\mathrm{C}$ & $\mathrm{T}$ & $\mathrm{A}$ & $\mathrm{T}$ & $\mathrm{C}$ & & $\mathrm{T}$ \\
\hline $\begin{array}{l}\text { Novel haplotype found in } \\
\text { honey bees from Serbia } \\
\text { (proposed designation) }\end{array}$ & & & & & & & & & \\
\hline C2E & & & & & & & & & \\
\hline
\end{tabular}

5 PS, Five previously described polymorphic sites;

8 PS, Eight polymorphic sites (five previously described + three novel)

*novel polymorphic site; ddeletion; insertion; tvtransversion

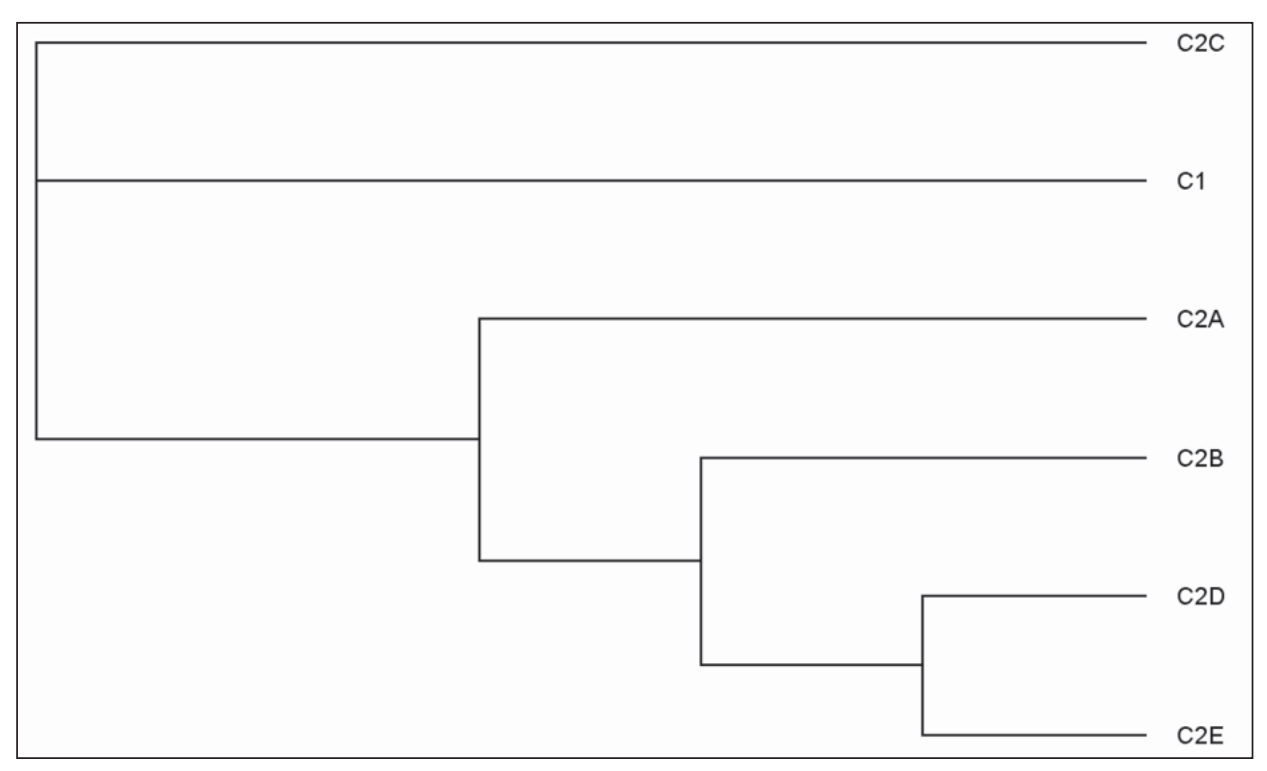

Figure 3. Inferred phylogeny of six honey bee haplotypes of the C mtDNA lineage constructed by parsimony and neighbour-joining methods 
Table 2. Pair-wise genetic distance estimates for six honey bee haplotypes of the $C$ mtDNA lineage (below the diagonal) and number of nucleotide differences between them (above the diagonal)

\begin{tabular}{|c|c|c|c|c|c|c|}
\hline Haplotypes & C1 & C2A & C2B & C2C & C2D & C2E \\
\hline \hline C1 & & 4 & 4 & 1 & 3 & 6 \\
\hline C2A & 0.0083 & & 2 & 3 & 1 & 4 \\
\hline C2B & 0.0083 & 0.0041 & & 3 & 1 & 4 \\
\hline C2C & 0.0020 & 0.0062 & 0.0062 & & 2 & 5 \\
\hline C2D & 0.0062 & 0.0021 & 0.0020 & 0.0041 & & 3 \\
\hline C2E & 0.0125 & 0.0083 & 0.0083 & 0.0104 & 0.0062 & \\
\hline
\end{tabular}

\section{DISCUSSION}

Our results show that the honey bee ecotypes from Serbia included in this study belong to the C2D mtDNA haplotype. However, three novel polymorphic sites were found in analysed sequences of all samples. For the novel mtDNA haplotype the designation $\mathrm{C} 2 \mathrm{E}$ is proposed. This unique mtDNA haplotype, only found so far in honey bees from Serbia (C2E haplotype), differs from the C2D haplotype in two A-T transversions and one insertion. The pair-wise genetic distance between C2E and C2D haplotype was 0.0062 , but distances between the C2E haplotype and other haplotypes within $\mathrm{C}$ mtDNA lineage were even greater (0.0083-0.0125). Moreover, a phylogenetic tree reveals clear separation of the C2E haplotype from other haplotypes of the $\mathrm{C}$ mtDNA lineage. These findings may imply that honey bees from Serbia represent an indigenous gene pool within A. $m$. carnica. Considering the fact that the territory of Serbia was a refuge region during the Pleistocene ice period the C2E haplotype may be a relic native variant, i.e. an indigenous mtDNA haplotype found in honey bees from Serbia.

The C2D mtDNA haplotype was first described by Sušnik et al. (2004) in samples of $A$. m. macedonica and "Buckfast $\mathrm{J}$ " selected line of bees from Germany. Samples of $A$. $m$. macedonica were highly differentiated from all other populations analysed and showed less intra-group variability than other analysed groups (Sušnik et al., 2004). Considering the native range of $A$. $m$. carnica and $A$. $m$. macedonica our discovery of the C2D mtDNA haplotype can be interpreted as the result of a northward invasion of $A$. $m$. macedonica along river basins during the past. However, in phylogeographical studies of honey bee populations, and especially in the Mediterranean area, one has also to take into account the possible human influences during historic times (Franck et al., 2000b). The importation of foreign queens and the practice of moving hives several times per year are factors that can affect the genetic structure of a local honey bee population through genetic introgression. When importations are reiterated every year, mtDNA is more quickly introgressed than nuclear genes (Garnery et al., 1998). Besides, several technical improvements introduced in beekeeping 
management may interfere with the natural distribution of populations (Bouga et al., 2005). However, we tried to minimize human influence by sampling bees only from small apiaries with woven skeps that had existed on the same sites at least 50 years and where foreign queens had never been introduced.

Despite their close geographic relationship, A. m. carnica and A. $m$. macedonica are readily differentiated using morphometric analysis (Ruttner, 1988; Arias and Sheppard, 1996). However, morphometric data are not very well suited for inferring population structure (especially introgression) within the species Apis mellifera, since selective factors may result in convergence (Bouga et al., 2005). In recent work by Sušnik et al. (2004), samples of $A$. m. macedonica formed the most distinct group among the populations analysed and were highly differentiated and separated from the A. m. carnica samples from Slovenia and Croatia, based on both mtDNA and microsatellite markers. Moreover, Bouga et al. (2005) report sharp genetic differentiation between $A$. $m$. macedonica populations and other neighboring subspecies populations (A. m. adami, A. m. cecropia and A. $m$. cypria) based on mtDNA markers. Thus, our findings on the C2D mtDNA haplotype require furher investigation of honey bees from Serbia, using both, microsatellites and mtDNA markers, in order to determine the genetic structure of these bees and to examine its relationship to the neighboring populations. Considering the described ranges of $A$. m. carnica and $A$. m. macedonica (Ruttner, 1988), it would be preferable to sample bees from a wider area including the southern parts of Serbia (Kosovo) and the whole territory of Republic of Macedonia (former Yugoslav Republic of Macedonia) since molecular data regarding honey bees from these regions are lacking.

Within the T honey bee ecotype we revealed the existence of two additional polymorphic sites in the COI-COll region: deletion (in $40 \%$ of samples) and T-C transition (in 10\% of samples). These findings indicate a certain differentiation of the $T$ ecotype from the other two investigated ecotypes from Serbia, while no differences were found between $B$ and $S$ ecotypes. The heterogeneity in mtDNA $\mathrm{COI}-\mathrm{CO}$ Il region within the $\mathrm{T}$ honey bee ecotype may result from the accumulation of genetic changes during the Pleistocene ice period. Also, human influence can not be excluded, even though we made an effort to sample bees only from traditional hives which have never been moved, and where beekeepers have not imported foreign queens. However, further investigations are needed to provide better insight in the genetic diversity and phylogeography of honey bee populations from the Timok region. Such investigations should also contribute to the conservation of local honey bee ecotypes.

In conclusion, the results of this study justify the introduction of a new mtDNA haplotype (C2E), which is so far found only in honey bees from the territory of Serbia. The presence of this unique mtDNA haplotype in all honey bee samples from three distinctive regions of Serbia indicates an indigenous conserved gene pool. The facts that the C2D mtDNA haplotype was found in all samples of Serbian A. m. carnica (based on morphology, unpublished), and that all samples of $A$. m. macedonica were monomorphic for the same haplotype (Sušnik et al., 2004) suggest that this haplotype may be found within both subspecies. 


\section{ACKNOWLEDGEMENTS:}

This study was supported by the Ministry of Science and Environmental Protection of the Republic of Serbia (Grant No. 143022). We are especially grateful to Dr Ingemar Fries for critical reading and helpful suggestions and Dr Robert Glinwood for linguistic improvements of the manuscript.

Address for correspondence:

Jevrosima Stevanović

Department of Biology,

Faculty of Veterinary Medicine,

University of Belgrade, 11000 Belgrade,

Bul. oslobodjenja 18,

Serbia

e-mail: rocky@vet.bg.ac.yu

\section{REFERENCES}

1. Arias MC, Sheppard WS, 1996, Molecular phylogenetics of honey bee subspecies (Apis mellifera L.) inferred from mitochondrial DNA sequence, Mol Phylogenet Evol, 5, 557-66.

2. Avise JC, Arnold J, Ball RM, 1987, Intraspecific phylogeography: the mitochondrial DNA bridge between population genetics and systematics, Annu Rev of Ecol Syst, 18, 489-522.

3. Bouga M, Harizanis PC, Kilias G, Alahiotis S, 2005, Genetic divergence and phylogenetic relationships of honey bee Apis mellifera (Hymenoptera: Apidae) populations from Greece and Cyprus using PCR - RFLP analysis of three mtDNA segments, Apidologie, 36, 335-44.

4. Bowtell DD, 1987, Rapid isolation of eukaryotic DNA, Anal Biochem, 162, 463-5.

5. Cornuet JM, Garnery L, Solignac M, 1991, Putative origin and function of the intergenic region COI and COII of Apis mellifera L. mitochondrial DNA, Genetics, 1128, 393-403.

6. De la Rúa P, Gallián J, Serrano J, Moritz RFA, 2001a, Genetic structure and distinctness of Apis mellifera L. populations from the Canary Islands, Mol Ecol, 10, 1733-42.

7. De la Rúa P, Gallián J, Serrano J, Moritz RFA, 2001b, Molecular characterization and population structure of the honeybees from the Balearic islands (Spain), Apidologie, 32, 417-27.

8. De la Rúa P, Gallián J, Pedersen BV, Serrano J, 2006, Molecular characterization and population structure of Apis mellifera from Madeira and the Azores, Apidologie, 37, 699-708.

9. Franck P, Garnery L, Solignac M, Cornuet JM, 1998, The origin of west European subspecies of honeybees (Apis mellifera): New insights from microsatellite and mitochondrial data, Evolution, 52, 1119-34.

10. Franck P, Garnery L, Solignac M, Cornuet JM, 2000a, Molecular confirmation of a fourth lineage in honeybees from Middle-East, Apidologie, 31, 167-80.

11. Franck P, Garnery L, Celebrano G, Solignac M, Cornuet JM, 2000b, Hybrid origins of honeybees from Italy (Apis mellifera ligustica) and Sicily (A. m. sicula), Mol Ecol, 9, 907-21.

12. Franck P, Garnery L, Loiseau A, Oldroyd BP, Hepburn HR, Solignac M, Cornuet JM, 2001, Genetic diversity of the honeybee in Africa: microsatellite and mitochondrial data, Heredity, 86, 420-30.

13. Garnery L, Cornuet JM, Solignac M, 1992, Evolutionary history of the honey bee Apis mellifera inferred from mitochondrial DNA analysis, Mol Ecol, 1, 145-54.

14. Garnery L, Solignac M, Celebrano G, Cornuet JM, 1993, A simple test using restricted PCRamplified mitochondrial DNA to study the genetic structure of Apis mellifera L, Experientia, 49, 1016-21.

15. Garnery L, Franck P, Baudry E, Vautrin D, Cornuet JM, Solignac M, 1998, Genetic diversity of the west European honeybee (Apis mellifera mellifera and Apis mellifera iberica). II. Microsatellite loci, Genet Sel Evol, 30, 49-74.

16. Hall TA, 1999, BioEdit: a user-friendly biological sequence alignment editor and analysis program for Windows 95/98/NT, Nucleic Acids Symposium Series, 41, 95-8.

17. Kandemir I, Kence M, Sheppard WS, Kence A, 2006a, Mitochondrial DNA variation in honey bee (Apis mellifera L.) population from Turkey, J Apic Res, 45, 33-8. 
18. Kandemir I, Meixner MD, Ozkan A, Sheppard WS, 2006b, Genetic characterization of honey bee (Apis mellifera cypria) populations in northern Cyprus, Apidologie, 37, 547-55.

19. Meixner MD, Sheppard WS, Poklukar J, 1993, Asymmetrical distribution of a mitochondrial DNA polymorphism between 2 introgressing honey bee subspecies, Apidologie, 24, 147-53.

20. Meixner MD, Arias MC, Sheppard WS, 2000, Mitochondrial DNA polymorphism in honeybee subspecies from Kenya, Apidologie, 31, 181-90.

21. Meusel MS, Moritz RFA, 1993, Transfer of paternal mitochondrial DNA in fertilization of honeybees (Apis mellifera L.) eggs, Curr Genet, 24, 539-43.

22. Moritz RFA, Cornuet JM, Kryger P, Garnery L, Hepburn HR, 1994, Mitochondrial-DNA variability in South African honeybees (Apis mellifera L.), Apidologie, 25, 169-78.

23. Palmer MR, Smith DR, Kaftanoglu O, 2000, Turkish honeybees: genetic variation and evidence for a fourth lineage of Apis mellifera mtDNA, $J$ Hered, 91, 42-6.

24. Ruttner $F, 1988$, Biogeography and taxonomy of honeybees. Springer-Verlag; Berlin, Germany, 284

25. Ruttner F, 1992, Naturgeschichte der Honigbienen, Ehrenwirth Verlag; München, Germany, 357 pp.

26. Sheppard WS, Rinderer TE, Meixner MD, Yoo HR, Stelzer JA, Schiff NM, Kamel SM, Krell R, 1996 Hinf1 variation in mitochondrial DNA of old world honey bee subspecies, $J$ Hered, 87, 35-40.

27. Smith DR, Brown WM, 1988, Polymorphisms in mitochondrial DNA of European and Africanized honeybees (Apis mellifera), Experientia, 44, 257-60.

28. Smith DR, Palopoli MF, Taylor BR, Garnery L, Cornuet JM, Solignac M, Brown M, 1991, Geographical overlap of two mitochondrial genomes in Spanish honeybees (Apis mellifera iberica), J Hered, 82, 96-100.

29. Stanimirovic Z, Popeskovic D, Pejovic D, 1999a, Biodiversity of the honeybee Apis mellifera, Linne (1758), from the Yugoslav regions: I - The biometric variability of the chromosomes of the Banat and Syenichko-Peshterski ecotypes, Acta Vet, Beograd, 49, 199-206.

30. Stanimirovic Z, Vucinic M, Stevanovic J, 1999b, Biodiversity of the honeybee Apis mellifera, Linne (1758), from some Yugoslav regions: II - Ultrastructural chromosomal differences between Banat and Syenichko-Peshterski honeybee ecotype, Acta Vet, Beograd, 49, 207-14.

31. Stanimirovic Z, Pejovic D, Stevanovic J, Vucinic M, Mirilovic M, 2002, Investigations of hygienic behaviour and disease resistance in organic beekeeping of two honeybee ecogeographic varieties from Serbia, Acta Vet, Beograd, 52, 169-80.

32. Stanimirovic Z, Stevanovic J, Cirkovic D, 2003, Investigations of reproductive, productive, hygienic and grooming features of Syenichko-Peshterski honey bee ecotype, Apidologie, 34, 487-8.

33. Stanimirovic Z, Stevanovic J, Andjelkovic M, 2005a, Chromosomal diversity in Apis mellifera carnica from Serbia, Apidologie 36, 31-42.

34. Stanimirovic Z, Stevanovic J, Cirkovic D, 2005b, Behavioural defenses of the honey bee ecotype from Sjenica - Pester against Varroa destructor, Acta Vet, Beograd, 55, 69-82.

35. Stevanovic J, 2002, Investigations of morphometric and chromosomal variability in diversity preserving of Carniolan honey bee (Apis mellifera carnica Pollmann, 1879) in Serbia, MSc. thesis, Belgrade University, Yugoslavia.

36. Sušnik S, Kozmus P, Poklukar J, Meglič V, 2004, Molecular characterisation of indigenous Apis mellifera carnica in Slovenia, Apidologie, 35, 623-36.

37. Thompson JD, Gibson TJ, Plewniak F, Jeanmougin F, Higgins DG, 1997, The ClustalX windows interface: flexible strategies for multiple sequence alignment aided by quality analysis tools, Nucleic Acids Res, 24, 4876-82. 


\section{ANALIZA MITOHONDRIJALNE DNK KOD MEDONOSNIH PČELA (APIS MELLIFERA) IZ SRBIJE}

KOZMUS P, STEVANOVIĆ JEVROSIMA, STANIMIROVIĆ Z, STOJIĆ V, KULIŠIĆ Z i MEGLIČ V

SADRŽAJ

U ovom radu su prikazani rezultati analize mitohondrijalne DNK autohtonih populacija medonosne pčele iz Srbije. Istraživanje je obuhvatilo tri ekotipa: Banatski (B), Sjeničko-Pešterski (S) i Timočki (T). Rezultati ukazuju da svi ispitivani uzorci medonosne pčele iz Srbije pripadaju jednom mtDNK haplotipu C filogenetske linije, ranije označenom kao C2D haplotip, mada sa tri polimorfna mesta više. Za novi mtDNK haplotip predložena je oznaka C2E. Novi C2E haplotip razlikuje se od C2D haplotipa u dve A-T transverzije i jednoj inserciji. Osim toga, u okviru T ekotipa medonosne pčele uočena su još dva polimorfna mesta, delecija nukleotida T i T-C tranzicija. Ovi rezultati ukazuju da populacije kranjske medonosne pčele iz Srbije mogu pretstavljati autohtoni genski pul u okviru podvrste A. m. carnica. Mitohondrijalni DNK haplotip C2D, koji je prethodno opisan kod A. m. macedonica, utvrđen je u svim uzorcima A. m. carnica iz Srbije. Ovakav nalaz sugerise da C2D haplotip može postojati kod obe podvrste. Ovaj rad predstavlja prvi pokušaj da se obavi karakterizacija autohtonih populacija medonosne pčele u Srbiji primenom molekularnih tehnika, a u cilju boljeg razumevanja filogeografije vrste Apis mellifera. 